\title{
PROFIL STRATEGI PEMBELAJARAN BAHASA JEPANG KELAS XI BAHASA 1 DI SMA NEGERI 1 BUSUNGBIU
}

\author{
I. M. R. Antara ${ }^{1}$, G. S. Hermawan ${ }^{2}$, N. N. Suartini ${ }^{3}$ \\ ${ }^{123}$ Jurusan Pendidikan Bahasa Jepang, Universitas Pendidikan Ganesha, Singaraja \\ e-mail: made.antara@undiksha.ac.id, satya.hermawan@undiksha.ac.id,nnsuartini@undiksha.ac.id
}

\begin{abstract}
Abstrak
Penelitian ini bertujuan untuk mendeskripsikan (1) strategi pembelajaran yang digunakan oleh guru untuk mencapai sasaran pembelajaran bahasa Jepang pada kelas XI bahasa 1 di SMA Negeri 1 Busungbiu, (2) kendala-kendala yang dihadapi dalam kegiatan pembelajaran bahasa Jepang kelas XI bahasa 1 di SMA Negeri 1 Busungbiu. Subjek penelitian ini adalah guru bahasa Jepang di kelas XI bahasa 1 SMA Negeri 1 Busungbiu. Pengumpulan data dilakukan dengan metode observasi, wawancara, dokumentasi, dan simak catat, kemudian dianalisis dengan metode deskriptif kualitatif. Hasil penelitian menunjukkan bahwa (1) Strategi pembelajaran yang digunakan oleh guru untuk mencapai sasaran pembelajaran bahasa Jepang pada kelas XI bahasa 1 di SMA Negeri 1 Busungbiu, strategi pembelajaran yang digunakan yaitu strategi kontekstual, ceramah, drill, tanya jawab, dan diskusi sedangkan sasaran pembelajaran bahasa Jepang yaitu agar siswa mampu mengembangkan keterampilan dasar berbahasa Jepang yang meliputi aspek mendengarkan, berbicara, membaca, dan menulis; (2) Kendala yang dihadapi dalam kegiatan pembelajaran bahasa Jepang kelas XI bahasa 1 di SMA Negeri 1 Busungbiu yaitu pada saat guru memberikan choukai ke pada siswa, siswa masih agak susah menangkap percakapan yang dimaksud dan terkendala dalam menghafal kosakata.
\end{abstract}

Kata kunci: pembelajaran, profil, strategi pembelajaran

\section{要旨}

本研究は、（1）日本語を教えている第 1 ブスングビウ国立高校主に日本語を教え る教師の学習方法を解析する事である。（2）第 1 ブスングビウ国立高校の使徒の 学習問題点。この研究の対象は第 1 ブスングビウ国立高校の日本語を教える教師で ある。書類収集の方法は観察、インタビュー、ドキュメンタリーでと注を参照。そ れでデータを定性的記述法により分析した。（1）研究の結果は教師が扱ってる学習 方法は文脈的、御喋り、ドリル、質問と回答、でと議論。しながら日本語能力、読 み、書き、聞くを含まれてある。（2）第 1 ブスングビウ国立高校生徒の問題点は 聴解を学習する時生徒はあまり会話を聞き取れない。

キーワード：学習、紹介、ストラテジー

\section{Pendahuluan}

Dalam proses pembelajaran terdapat beberapa komponen penting yang saling mempengaruhi antara satu dengan yang lainnya. Proses pembelajaran akan berjalan dengan efektif dan efisien apabila komponen-komponen tersebut dapat berinteraksi dengan baik. Guru bertindak melaksanakan proses pembelajaran agar tujuan dari proses tersebut dapat tercapai secara optimal. Oleh karena itu, guru diharapkan mengetahui dan memahami hakikat pembelajaran termasuk strategi pembelajaran.

Strategi pembelajaran merupakan perencanaan hal-hal yang akan dilakukan dalam kegiatan belajar mengajar untuk mencapai suatu tujuan pembelajaran dengan efektif dan efisien. Dengan adanya strategi yang jelas, proses pembelajaran akan terarah sehingga guru memiliki pedoman dan acuan bertindak yang sistematis dalam pelaksanaan pembelajaran yang berlangsung, serta mempermudah proses pembelajaran.

Pada umumnya, bahasa Jepang mulai diperkenalkan pada jenjang sekolah menengah pertama atau menengah atas. Terdapat banyak strategi atau teknik pembelajaran yang sudah dikembangkan oleh para ahli bahasa dalam pembelajaran bahasa Jepang sebagai bahasa asing. Kemampuan siswa dalam mempelajari bahasa asing terutama dalam 
mempelajari bahasa Jepang dapat dilihat dari metode, strategi atau teknik, dan variasi pembelajaran yang digunakan oleh guru dalam proses pembelajaran. Metode strategi atau teknik yang digunakan hendaknya sesuai dengan kompetensi indikator, dan tujuan pembelajaran. Selain itu, untuk memperoleh hasil pembelajaran yang sesuai dengan tujuan pembelajaran, guru harus bisa menentukan cara untuk mengatur lingkungan belajar siswa agar mereka memiliki pengalaman belajar yang dapat mengarahkan mereka untuk mencapai hasil belajar yang diinginkan. Metode strategi atau teknik yang dipilih dalam proses pembelajaran, diharapkan sesuai dengan tujuan pembelajaran. Seorang guru harus bisa menggunakan strategi mengajar yang dapat menarik minat belajar siswa dan mampu menerapkan dengan berbagai strategi yang bervariasi. Dengan demikian keadaan pembelajaran di dalam kelas tidak monoton. Keadaan pembelajaran yang monoton akan membuat siswa merasa bosan sehingga siswa kurang memahami tentang pembelajaran yang diberikan oleh guru.

Pada penelitian ini, profil yang akan dipaparkan adalah tentang profil strategi pembelajaran bahasa Jepang di SMA Negeri 1 Busungbiu. Penelitian ini akan menjelaskan dua hal, pertama, tentang strategi pembelajaran yang digunakan oleh guru untuk mencapai sasaran pembelajaran bahasa Jepang pada kelas XI bahasa 1 di SMA Negeri 1 Busungbiu; kedua, kendala-kendala yang dihadapi dalam kegiatan pembelajaran bahasa Jepang kelas XI bahasa 1 di SMA Negeri 1 Busungbiu.

SMA Negeri 1 Busungbiu merupakan sekolah yang tetap menggunakan kurikulum 2013 pada mata pelajaran bahasa asing, termasuk didalamnya bahasa Jepang. Mata pelajaran bahasa Jepang sesuai dengan kurikulum 2013 dimasukkan ke dalam mata pelajaran pilihan atau peminatan akademik, akan tetapi, pada SMA Negeri 1 Busungbiu bahasa Jepang sebagai mata pelajaran wajib pada kelas bahasa.

SMA Negeri 1 Busungbiu menerapkan kurikulum 2013, dan mengajarkan mata pelajaran bahasa Jepang dimulai dari kelas $X$ khusus untuk kelas peminatan bahasa. Setiap sekolah memiliki sistem dan kebijakannya sendiri, oleh karena itulah SMA Negeri 1 Busungbiu hanya memasukan mata pelajaran bahasa Jepang khusus pada kelas peminatan bahasa dan tidak diajarkan pada kelas IPA dan IPS.

SMA Negeri 1 Busungbiu saat ini sebagai salah satu SMA di Kabupaten Buleleng yang diminati oleh siswa terlihat dari tahun ke tahun siswa yang memilih jurusan bahasa selalu meningkat dari tahun 2016 siswa yang memilih jurusan bahasa sebanyak 59 orang, tahun 2017 siswa yang memilih jurusan bahasa meningkat lagi sebanyak 66 orang,dan ditahun 2018 siswa yang memilih jurusan bahasa meningkat lagi sebanyak 72 orang. Hal ini dikarenakan sekolah ini secara konsisten mengupayakan pelayanan pendidikan yang ramah anak, dan optimal baik dari segi proses pembelajaran serta peningkatan sarana prasarana. Pada proses pembelajaran, khususnya pada kelas bahasa, sekolah ini sebagai salah satu sekolah yang masih menjadikan mata pelajaran bahasa Jepang sebagai mata pelajaran wajib dimulai dari kelas $X$, dengan alokasi pembelajaran bahasa Jepang 4 jam pelajaran per minggu untuk masing-masing kelas, dengan jumlah kelas XI bahasa sebanyak 66 siswa.

Dari hasil observasi dilakukan ke kelas XI bahasa 1 pada saat guru mengajar di kelas terlihat bahwa guru berusaha untuk mengajarkan siswa dengan menggunakan strategi kontekstual. Strategi kontekstual adalah satu strategi pembelajaran yang menekankan kepada proses keterlibatan siswa secara penuh untuk dapat menemukan materi yang dipelajari dan menghubungkannya dengan situasi kehidupan nyata sehingga mendorong siswa untuk dapat menerapkannya dalam kehidupan mereka, terlihat di dalam observasi guru menekankan contoh-contoh yang berkaitan terhadap kehidupan-kehidupan di Bali.

Guru tidak bisa menerima kalimat dari siswa yang tidak ada hubungannya dengan kehidupan di Bali, misalnya kalimat saya pergi ke sekolah dengan kereta listrik, densha de gakko he ikimasu (でんしゃ でがっこへいきます). Guru tidak menerima kalimat tersebut bukan karena kalimat itu salah, tetapi karena di Bali tidak ada yang menggunakan kereta listrik. Di Busungbiu, siswa hanya menggunakan sepeda atau jalan kaki, maka siswa diminta untuk membuat satu contoh kalimat yang sesuai dengan kehidupan yang sebenarnya ada di Bali. Dengan ini maka guru mencoba untuk menggunakan strategi kontekstual, walaupun dari hasil wawancara guru tidak merasa melakukan hal tersebut hal ini menarik untuk dikaji, dan pada saat pembelajaran bahasa Jepang ditemukan juga guru menggunakan media audio untuk Dounyuu dimana guru disini memperkenalkan kosakata baru dengan 
menggunakan media audio. guru melatih pendengaran siswa agar siswa lebih terbiasa mendengarkan bahasa Jepang dan lebih paham dengan materi yang didengarkan secara langsung. Guru memberikan fukushuu dan kihon renshuu yang diambil dari buku "Nihongo Kira-Kira" saja. Menariknya, guru tidak mengambil contoh dari sumber buku lainnya, hal ini menarik untuk dikaji.

Dari hasil wawancara yang telah dilakukan dengan ibu Komang Tri Budi Utami,S.Pd. selaku guru pengajar bahasa Jepang di SMA Negeri 1 Busungbiu, wawancara ini dilakukan hanya dengan satu narasumber saja, karena hanya terdapat satu guru yang mengajar bahasa Jepang di SMA tersebut. Wawancara ini dilakukan untuk mengetahui gambaran awal mengenai situasi pembelajaran bahasa Jepang strategi serta kendalanya. Dalam wawancara tersebut guru mengungkapkan bahwa siswa kelas XI bahasa 1 rata-rata menyukai pembelajaran bahasa Jepang karena bahasa Jepang itu sangat menarik sekali untuk dipelajari, menurut guru alasan siswa menyukai bahasa Jepang, bahasa Jepang itu menantang untuk dipelajari dan siswa menyukai pelajaran bahasa Jepang karena ingin bisa berbahasa Jepang dengan baik dan ingin mengenal lebih dalam tentang budaya Jepang.

Pada saat observasi dilakukan ke kelas terlihat kondisi kelas dalam pembelajaran bahasa Jepang, siswa sangat aktif pada saat menjawab pertanyaan, namun untuk daya tangkap siswa belajar, siswa masih lambat menerima konsep yang diajarkan oleh guru. Namun demikian, siswa sangat semangat mengikuti pelajaran, siswa di sana belajar tidak hanya mendengarkan dari guru saja tapi siswa juga suka belajar dengan mencari sumber sendiri melalui buku yang siswa bawa. Siswa - siswa disana juga berprestasi dalam pelajaran bahasa jepang karena salah satu siswa pernah dapat ikut mewakili sekolah dalam perlombaaan bahasa Jepang yang pernah diselenggarakan oleh universitas pendidikan Ganesha yaitu jurusan bahasa Jepang. Walaupun hanya sampai sepuluh besar. Jadi, dari hasil wawancara ini, ditemukan bahwa siswa memiliki minat yang besar terhadap bahasa Jepang walaupun kemampuan dapat dikatakan kurang.

Dari hasil observasi yang dilakukan pada hari Rabu, 10 April 2019 jam ke 1-2 (07:3009:45) pada saat pembelajaran yang diajarkan oleh guru dengan tema yang diajarkan adalah "basude gakkou he ikimasu", terlihat guru melakukan Dounyuu dua kali yang dimana sistem proses pembelajaran guru adalah dounyuu setelah dounyuu masuk ke kihon renshuu setelah kihon renshuu masuk ke ouyou renshuu, namun disini dilihat dari observasi yang dilakukan ke kelas terlihat gurunya melakukan dounyuu habis dounyuu masuk ke kihon renshuu dan habis ke kihon renshuu masuk ke ouyou renshuu dan setelah ouyou reshuu dilakukan, kembali lagi melakukan dounyuu, jadi dalam observasi yang dilakukan terlihat guru melakukan dounyuu 2 kali dan terakhir siswanya langsung diberikan tes kecil pada akhir pelajaran, disini juga terlihat jika siswanya salah menjawab maka siswa bersangkutan langsung mendapatkan hukuman jongkok bangun 5 kali, namun demikian siswanya masih tetap semangat mengikuti pelajaran di kelas.

Berdasarkan pemaparan tersebut diketahui bahwa alasan memilih sekolah dan memilih profil strategi pembelajaran bahasa Jepang dikarenakan guru di SMA Negeri 1 Busungbiu menggunakan strategi kontekstual, ceramah, drill, tanya jawab, dan diskusi serta guru menggunakan media audio untuk dounyuu yang dilakukan sebanyak dua kali, dan ada kendala-kendala yang dihadapi guru dalam proses pembelajaran bahasa Jepang di kelas XI bahasa 1 SMA Negeri 1 Busungbiu yaitu pada saat guru memberikan choukai kepada siswa, siswa masih agak susah menangkap percakapan yang dimaksud dan terkendala dalam menghafal koskata, maka dengan itu peneliti tertarik melakukan penelitian dengan judul "Profil Strategi Pembelajaran Bahasa Jepang Kelas XI Bahasa 1 di Sma Negeri 1 Busungbiu".

Adapun rumusan masalah dari penelitian in adalah sebagai berikut.

1. Bagaimana strategi pembelajaran yang digunakan oleh guru untuk mencapai sasaran pembelajaran bahasa Jepang pada kelas XI bahasa 1 di SMA Negeri 1 Busungbiu?

2. Apa kendala yang dihadapi dalam kegiatan pembelajaran bahasa Jepang kelas XI bahasa 1 di SMA Negeri 1 Busungbiu? 
Penelitian ini menggunakan beberapa teori menggunakan beberapa teori yang mendukung proses penelitian. Landasan teori yang digunakan adalah 1) Teori pembelajaran bahasa asing 2) Teori strategi pembelajaran bahasa 3) Teori metode pembelajan bahasa asing 4) Teori kendala dalam pembelajaran.

Dalam penelitian ini membahas tentang profil strategi pembelajaran yang digunakan dalam proses pembelajaran bahasa Jepang dan difokuskan pada strategi pembelajaran yang digunakan oleh guru untuk mencapai sasaran pembelajaran bahasa Jepang pada kelas XI bahasa 1 di SMA Negeri 1 Busungbiu dan kendala-kendala yang dihadapi dalam kegiatan pembelajaran bahasa Jepang.

\section{Metode}

\section{Pendekatan dan Jenis Penelitian}

Penelitian ini mengggunakan metode deskriptif kualitatif. Tujuan dari penelitian deskriptif kualitatif ini adalah untuk membuat deskripsi, gambaran, atau lukisan secara sistemtis, faktual,, dan akurat mengenai fakta-fakta, sifat-sifat serta hubungan antar fenomena yang diselidiki. Penelitian ini akan mendeskripsikan secara kualitatif tentang profil strategi pembelajaran bahasa Jepang kelas XI bahasa 1 di SMA Negeri 1 Busungbiu.

Lokasi penelitian adalah merupakan suatu tempat atau wilayah dimana penelitian tersebut akan dilakukan. Penelitian ini dilakukan di SMA Negeri 1 Busungbiu yang terletak di jalan Amerta No XX, desa Busungbiu, kecamatan busungbiu, kabupaten Buleleng.

\section{Subjek dan Objek Penelitian}

Suandi (2008:31) mengatakan subjek penelitian merupakan benda, hal, atau orang tempat variabel melekat dan yang dipermasalahkan dalam penelitian. Dengan demikian, subjek dalam penelitian ini adalah guru bahasa Jepang di SMA Negeri 1 Busungbiu.

Sementara itu, objek penelitian menurut Sugiyono (2010:298) merupakan hal yang ingin dipahami secara mendalam tentang "apa yang terjadi" objek penelitian dalam penelitian ini adalah profil strategi pembelajaran bahasa jepang kelas XI Bahasa 1 di SMA Negeri 1 Busungbiu. Dalam penelitian ini, yang menjadi objek penelitian adalah (1) bagaimana strategi pembelajaran yang digunakan oleh guru untuk mencapai sasaran pembelajaran bahasa Jepang pada kelas XI bahasa 1 di SMA Negeri 1 Busungbiu, (2) kendala yang dihadapi dalam pembelajaran bahasa Jepang. Kedua hal tersebut merupakan saasaran utama penelitian ini.

\section{Teknik Pengumpulan Data}

Metode pengumpulan data ini menurut Arikunto (dalam Suandi, 2008:39) berkaitan dengan cara yang digunakan peneliti untuk mengumpulkan data. Menurut Sugiyono (2007:193) kualitas pengumpulan data merupakan salah satu faktor penentu utama yang memengaruhi kualitas data hasil penelitian selain kualitas instrumen penelitian. Oleh karena itu, untuk mengumpulkan data yang tepat dalam suatu penelitian ini, peneliti menggunakan empat metode pengumpulan data, yaitu metode observasi, metode wawancara, metode dokumentasi, dan metode simak catat.

Metode observasi digunakan untuk mencari dan mendapatkan data terkait profil strategi pembelajaran bahasa Jepang kelas XI Bahasa 1 di SMA Negeri 1 Busungbiu. Observasi yang dilakukan merupakan observasi non-partisipan saat proses belajar mengajar di kelas.

Metode pengumpulan data dengan wawancara dilakukan dengan memberikan pertanyaan kepada guru bahasa Jepang kelas XI Bahasa 1 di SMA Negeri 1 Busungbiu. Dalam penelitian ini, wawancara yang digunakan adalah jenis wawancara terstruktur karena format wawancara yang berkaitan dengan pembelajaran bahasa Jepang di kelas XI Bahasa 1 SMA Negeri 1 Busungbiu sudah disiapkan sebelum wawancara dilakukan.

Metode dokumentasi digunakan untuk mendapatkan fakta yang bersumber pada tulisan, seperti buku, majalah, LKS, dokumen dan sebagainya. Metode simak catat digunakan untuk memproleh data dengan menyimak dari video dan catatan yang kita proleh dari observasi di kelas. 


\section{Teknik Analisis Data}

Metode analisis data dalam penelitian ini harus disesuaikan dengan jenis data yang dikumpulkan. Mengingat penelitian ini adalah penelitian deskriptif kualitatif menurut Sugiyono (2007:401), teknik analisis data yang dilakukan bersamaan dengan pengumpulan data. Dalam penelitian ini, peneliti menggunakan metode deskriptif kualitatif sebagai metode analisis data. Analisis data dengan menggunakan metode deskriptif kualitatif menurut Arikunto (2005:269) dilakukan dengan memberikan predikat kepada variabel yang diteliti sesuai dengan kondisi sebenarnya.

Berdasarkan metode ini, peneliti dapat menggunakan teori-teori relevan yang telah dipaparkan dalam kajian pustaka sebagai acuan bagi peneliti untuk mendalami objek penelitian. Menurut Miles dan Huberman (dalam Sugiyono, 2007:337) aktivitas dalam analisis data kualitatif dilakukan secara interaktif dan berlangsung secara terus menerus sampai tuntas. Analisis data deskriptif kualitatif diarahkan pada identifikasi dan klasifikasi untuk mendapatkan deskripsi yang jelas, rinci, dan memadai, berkenaan dengan profil strategi pembelajaran bahasa Jepang kelas XI Bahasa 1 di SMA Negeri 1 Busungbiu. Teknik analisis data yang digunakan dalam penelitian ini dapat dibagi menjadi lima langkah yaitu,(1) tabulasi data, (2) reduksi data, (3) deskripsi data, (4) klasifikasi data, dan (5) penarikan kesimpulan.

\section{Hasil dan Pembahasan Hasil Penelitian}

Data ini diambil melalui hasil observasi dan hasil wawancara dideskripsikan sesuai dengan fakta yang ditemukan di lapangan. Pendeskripsian ini dilakukan berdasarkan sub masalah yang telah dipaparkan dalam rumusan masalah.

\section{Pembahasan}

berdasarkan hasil observasi yang dilakukan sebanyak lima kali ditemukan beberapa strategi pembelajaran yang digunakan oleh guru pada saat pembelajaran bahasa Jepang di kelas XI bahasa 1.

Strategi kontekstual ini terlihat pada saat observasi I yang dilakukan di kelas XI bahasa 1 yaitu guru menekankan contoh-contoh yang berkaitan terhadap kehidupan-kehidupan di Bali. Guru tidak bisa menerima kalimat dari siswa yang tidak ada hubungannya dengan kehidupan di Bali, misalnya kalimat saya pergi ke sekolah dengan kereta listrik, densha de gakko he ikimasu (でんしゃで がっこへいきます). Guru tidak menerima kalimat tersebut bukan karena kalimat itu salah, tetapi karena di Bali tidak ada yang menggunakan kereta listrik. Di Busungbiu, siswa hanya menggunakan sepeda atau jalan kaki, maka siswa diminta untuk membuat satu contoh kalimat yang sesuai dengan kehidupan yang sebenarnya ada di Bali.

Strategi pembelajaran kontekstual yang digunakan oleh guru pada saat pembelajaran guru mengaitkan antara materi yang diajarkan dengan situasi dunia nyata siswa dan mendorong siswa membuat hubungan antara pengetahuan yang dimilikinya dengan penerapannya dalam kehidupan mereka sebagai anggota masyarakat. Hal ini sejalan dengan yang diungkapkan oleh Umbara (2006).

Strategi kontekstual digunakan oleh guru pada saat pembelajaran dikelas, guru terlihat berusaha menghubungkan isi bahan ajar dengan situasi dunia nyata serta penerapannya dalam kehidupan sehari-hari yang dilakukan oleh siswa di SMA Negeri 1 Busungbiu. Berdasarkan hasil observasi, pelaksanaan strategi kontekstual dalam proses pembelajaran bahasa Jepang di kelas XI SMA Negeri 1 Busungbiu, terlihat bahwa sebelum guru menyuruh siswa membuat contoh pola kalimat yang sesuai dengan kehidupan yang sebenarnya ada di bali, guru terlebih dahulu memberikan contoh pola kalimatnya dan mempraktekkannya. Guru juga langsung bertanya kepada siswa dan kalau ada siswa yang menjawab dengan kalimat yang tidak ada hubungannya dengan kehidupan di Bali, guru tidak bisa menerima kalimat tersebut dan menyuruh siswa mengulang menjawab sampai kalimat yang dibuat oleh siswa itu sesuai dengan kehidupan yang sebenarnya ada di Bali.

Strategi ceramah ini terlihat pada saat observasi pertama sampai observasi kelima yang dilakukan di kelas XI bahasa 1 yaitu pada saat guru memulai membuka pelajaran dan kegiatan inti pembelajaran dari masing-masing observasi pertama sampai kelima disana 
guru terlihat menggunakan strategi ceramah yaitu ketika guru memulai pembelajaran dan pada saat guru memperkenalkan kosakata, pola kalimat serta pada saat guru memberikan pertanyaan kepada siswa di sini akan terlihat apabila terdapat siswa yang tidak mendengarkan atau mempunyai kesibukan akan segera diketahui oleh guru dan memberikan teguran.

Ceramah merupakan cara mengajar yang paling tradisional. Cara mengajar dengan ceramah sering disebut sebagai teknik kuliah karena strategi ini digunakan untuk menyampaikan keterangan, informasi atau uraian tentang suatu pokok persoalan, serta masalah secara lisan (Roestiyah, 2008).

Strategi ini digunakan agar guru lebih mudah mengawasi ketertiban siswa dalam menyimak pelajaran, dikarenakan para siswa melakukan kegiatan yang sama. Apabila terdapat siswa yang tidak mendengarkan atau mempunyai kesibukan akan segera diketahui oleh guru dan diberikan teguran. Untuk menggunakan strategi ceramah secara murni itu tidak mudah, maka dalam pelaksanaannya perlu dikombinasikan dengan strategi pembelajaran yang lain sehingga proses belajar mengajar dapat berlangsung secara intensif.

Penggunaan strategi drill dalam proses pembelajaran terlihat di observasi ketiga, dimana penerapannya sesuai dengan tahapan pembelajaran bahasa Jepang dasar yakni pada tahapan Kihon renshuu(基本練習/ latihan dasar). Dalam penggunaan strategi drill guru melakukan kegiatan Hanpuku renshuu (反復練習) dengan cara memberikan latihan pengulangan pengucapan kosakata maupun pola kalimat baru secara berulang hingga siswa dapat melafalkan kosakata maupun kalimat dengan benar serta dapat mengingatnya. Hal ini disebut dengan Mim-Mem Method yaitu metode pembelajaran yang ditekankan pada meniru kemudian diingat dan dihafalkan oleh siswa. Hal ini sejalan dengan yang diungkapkan oleh Nuha (2012). Strategi drill lebih sering digunakan oleh guru ketika melakukan latihan mengenai kosakata dan pola kalimat baru, sehingga cocok untuk diterapkan dalam proses pembelajaran bahasa Jepang di kelas XI karena dapat mengembangkan keterampilan siswa dalam berbicara dan membuat siswa menjadi lebih aktif.

Matakupan (1994) menyatakan bahwa kemampuan kognitif peserta didik pada kelas tinggi mulai berkembang dan mulai tumbuhnya daya konsentrasi siswa, serta adanya minat siswa untuk belajar. Drill yang dilakukan oleh guru yaitu drill kosakata dan drill berbasis kalimat. Salah satu contoh drill yang dilakukan yaitu guru mengucapkan kosakata dalam bahasa Indonesia tanpa menggunakan media pembelajaran, kemudian siswa menjawab dengan menggunakan bahasa Jepang adalah sebagai berikut. Hal ini juga sesuai dengan teori tersebut guru di SMA Negeri 1 Busungbiu telah menerapkan drill kosakata dan drill pola kalimat contohnya.

Guru : "air"

Siswa : “みす[misu]” (siswa menjawab secara bersamaan)

Dalam penerapan strategi drill, guru tidak hanya menyebutkan kosakata dan kalimat kemudian siswa langsung menjawabnya, namun guru juga menunjuk beberapa orang siswa untuk menuliskan kosakata dan kalimat di papan tulis. Hal tersebut dilakukan karena kemampuan kognitif siswa yang berbeda-beda, sehingga dengan kedua cara penerapan strategi drill tersebut siswa mampu mengingat dan memahami materi yang dipelajari. Sejalan dengan temuan tersebut, Uno (2010) menyatakan bahwa perbedaan kemampuan kognitif siswa disebabkan oleh gaya belajar yang berbeda-beda antara satu siswa dengan siswa yang lainnya, dan terdapat tiga jenis gaya belajar siswa, yaitu gaya belajar visual, gaya belajar auditorial dan gaya belajar kinestetik.

Strategi drill yang diamati saat observasi, guru lebih sering menggunakan strategi drill di awal pembelajaran pada pengulangan materi sebelumnya dan kegiatan inti pembelajaran pada pengenalan kosakata dan pola kalimat baru kepada siswa. Drill yang diberikan oleh guru masih tergolong sederhana, yaitu berupa menebak, menulis, dan membaca kata. Strategi drill dilakukan secara berulang agar siswa lebih mudah untuk mengingat dan memahami materi yang dijelaskan. Hal tersebut sesuai dengan pendapat dari Roestiyah (2008) yang menyatakan bahwa drill merupakan strategi dalam pengajaran dengan melatih peserta didik terhadap bahan yang sudah diberikan agar memiliki keterampilan dari yang sudah dipelajari dan dilakukan secara berulang-ulang. Guru bahasa Jepang di kelas XI bahasa1 SMA Negeri 1 Busungbiu tidak menggunakan media gambar saat proses Jurnal Pendidikan Bahasa Jepang | 97 
pembelajaran melainkan menggunakan media audio.

strategi tanya jawab digunakan oleh guru dalam pembelajaran bahasa Jepang terlihat pada saat observasi pertama sampai observasi kelima, dan penerapannya sesuai dengan tahapan pembelajaran bahasa Jepang dasar yakni pada tahapan Kihon renshuu (基本練習/ latihan dasar). Guru melakukan kegiatan Outou renshuu (応答練習/ tanya jawab) dengan cara melakukan tanya jawab antara guru dengan siswa sehingga interaksi yang terjadi antara guru kepada siswa ataupun siswa kepada guru sama-sama aktif. Strategi tanya jawab merupakan strategi pembelajaran dalam bentuk pertanyaan yang harus dijawab terutama oleh guru kepada siswa, serta dapat juga dijawab dari siswa kepada guru. Hal ini sejalan dengan yang diungkapkan oleh Djamarah (2013). Contoh tanya jawab yang dilakukan oleh guru kepada salah satu siswa ketika belajar tentang materi makanan yang dimakan setiap pagi.

Guru : "yuni san asa-gohan nani o tabemasuka?"

Siswa : "niku o tabemasu"

Strategi tanya jawab dapat membuat siswa menjadi lebih aktif, dapat mengontrol keadaan kelas, dan melatih kemampuan berbicara siswa. Selain itu, guru juga memberikan kesempatan kepada siswa yang ingin bertanya terkait hal-hal yang belum jelas atau dimengerti. Dari sini terlihat jika Kemampuan kognitif siswa kelas XI bahasa 1 berada pada tingkat kelas tinggi sehingga sudah mulai berkembang dan mulai tumbuhnya daya konsentrasi siswa. Serta memiliki rasa ingin tahu yang tinggi dan adanya minat belajar siswa. Hal ini sejalan dengan yang diungkapkan oleh Matakupan (1994). Kegiatan tanya jawab ini dilakukan kepada seluruh siswa dengan menggunakan bahasa Indonesia maupun bahasa Jepang mengenai kosakata maupun kalimat yang masih tergolong sederhana yang telah dipelajari, dan bertujuan untuk mengukur pemahaman siswa terhadap penguasaan materi pelajaran dan mendorong siswa untuk bertanya kepada guru apabila terdapat hal-hal yang belum jelas atau dimengerti. Sejalan dengan temuan tersebut. Pada teori taksonomi Bloom (dalam Dimyati dan Mudjiono, 2006:26) menyatakan bahwa pada tahap pemahaman siswa telah mencapai kemampuan menangkap arti dan makna tentang hal yang dipelajari.

Berdasarkan hasil observasi, pelaksanaan strategi tanya jawab dalam proses pembelajaran bahasa Jepang di kelas XI SMA Negeri 1 Busungbiu terlihat bahwa tanya jawab yang dilakukan bukan lagi berupa "yes no questions", sehingga siswa sudah mampu merespon pertanyaan dari guru berdasarkan materi yang telah diajarkan sebelumnya. Walaupun pertanyaan yang diberikan masih berupa pertanyaan sederhana mengenai materi yang diajarkan dan guru lebih aktif bertanya untuk menarik perhatian siswa. Penggunaan strategi tanya jawab ini belum sampai pada tahap "information gap" yaitu strategi pembelajaran yang membentuk perbedaan atau kesenjangan informasi yang dimiliki oleh masing-masing siswa dan kesenjangan tersebut dapat dihilangkan dengan cara bertukar informasi yang dimiliki sesuai dengan ranah kognitif siswa sekolah menengah atas, yaitu pada ranah pengetahuan.

Strategi diskusi ini terlihat pada saat observasi kedua yang dilakukan di kelas XI bahasa 1 yaitu pada saat guru memulai kegiatan inti pembelajaran, disini guru terlihat menggunakan strategi diskusi yaitu ketika guru memulai kegiatan inti pembelajaran siswa disuruh menutup buku kembali dan siswa disuruh membuat kelompok kecil untuk mendiskusikan kosakata baru yang akan dipelajari.

Strategi Diskusi yang diamati saat observasi, guru menyuruh siswa membuat kelompok kecil untuk mendiskusikan kosakata baru yang akan dipelajari. Guru memberikan gambar kosakata yang sudah ada arti bahasa Indonesia dan guru menyuruh siswa untuk mendengarkan audia yang akan diputar guna untuk melengkapi arti dari kosakata tersebut ke bahasa Jepang yang akan diputarkan lewat audio. Setelah itu dari materi yang didengarkan oleh siswa melalui audio yang diputarkan tersebut, siswa menulis kosakata yang didengarkan. Berikutnya, siswa langsung mencari makna dari kosakata bahasa Jepang yang didengarkan tersebut dan disesuaikan dengan gambar yang ada di buku Nihongo KiraKira. Hal ini merupakan interaksi antara siswa dengan siswa atau siswa dengan gurunya untuk memecahkan masalah, menganalisis, dan memperdebatkan topik tertentu. Hal ini sejalan dengan yang diungkapkan oleh Aqib (2014). 
Berdasarkan pendapat yang telah dipaparkan tersebut, dapat disimpulkan bahwa diskusi merupakan kegiatan pembelajaran dimana terjadinya proses interaksi antar dua atau lebih individu untuk memecahkan masalah atau memperdebatkan topik tertentu, terlihat pada observasi kedua dimana siswa disuruh berdiskusi kepada teman untuk mengertikan suatu materi yang lumayan susah kalau dipelajari sendiri, maka di sana guru mencoba untuk menyuruh siswa berdiskusi kepada teman sebangku guna untuk bisa mengartikan suatu materi yang diberikan oleh guru.

Sasaran pembelajaran bahasa Jepang di kelas XI SMA Negeri 1 Busungbiu yaitu agar siswa mampu mengembangkan keterampilan dasar berbahasa Jepang, yang meliputi aspek menyimak, berbicara, membaca, dan menulis.

Sasaran pembelajaran pertama dapat dicapai dengan melatih pendengaran siswa melalui latihan pengucapan kosakata atau kalimat secara berulang-ulang, kemudian siswa mendengarkan kosakata atau kalimat tersebut. Tujuannya adalah agar siswa dapat membedakan pelafalan dan makna dari kosakata maupun kalimat tersebut. siswa dituntut untuk mampu menyimak yang disampaikan oleh guru, kemudian siswa menjawab menggunakan kosakata sesuai dengan yang telah dipelajari sebelumnya.

Sasaran pembelajaran yang kedua pada aspek berbicara yaitu agar siswa mampu melafalkan bunyi, kata, dan mengucapkan salam dalam bahasa Jepang. Sasaran pembelajaran ini dapat dicapai dengan memberikan latihan pengulangan kosakata maupun pola kalimat yang dilakukan dengan strategi drill dan tanya jawab kepada siswa tentang materi yang diajarkan. Guru akan langsung mengoreksi siswa apabila terdapat kesalahan dalam pelafalan kosakata maupun pola kalimat yang diberikan. Selain itu, siswa ditekankan untuk mengucapkan salam dalam bahasa Jepang ketika bertemu dengan orang lain di lingkungan sekolah sesuai dengan situasi pada saat itu.

Sasaran pembelajaran yang ketiga pada aspek membaca yaitu agar siswa mampu membaca kosakata dan contoh kalimat bahasa Jepang yang terdapat pada buku penunjang, namun praktik membaca ini tidak dapat diberikan kepada seluruh siswa melainkan hanya beberapa siswa saja dikarenakan alokasi waktu yang terbatas. Setelah membaca, guru meminta siswa untuk menerjemahkan kosakata maupun contoh kalimat yang terdapat pada buku penunjang, sehingga siswa tidak hanya mampu membaca kosakata dan kalimat bahasa Jepang, namun juga memahami makna dari kosakata dan kalimat tersebut. Selain itu, siswa juga ditekankan agar mampu membaca kosakata sesuai dengan cara membaca dalam bahasa Jepang

Sasaran pembelajaran yang keempat yaitu pada aspek menulis. siswa diharapkan mampu menuliskan kosakata dan kalimat menggunakan huruf hiragan dan katakana dengan baik dan benar. Sasaran pembelajaran ini dapat dicapai dengan memberikan latihan menuliskan kosakata dan contoh kalimat kemudian guru akan mengoreksi siswa apabila terdapat kesalahan pada penulisan kosakata dan kalimat.

Dari hasil pemaparan tersebut, dapat disimpulkan bahwa sasaran pembelajaran bahasa Jepang di kelas XI SMA Negeri 1, agar siswa mampu mengembangkan keterampilan dasar berbahasa Jepang yang meliputi aspek mendengarkan, berbicara, membaca, dan menulis.

Kendala yang dihadapi guru dalam proses pembelajaran bahasa Jepang di kelas XI bahasa 1 SMA Negeri 1 Busungbiu yaitu kendala yang dihadapi guru dalam pembelajaran bahasa Jepang yaitu pada saat guru memberikan choukai ke pada siswa, siswa masih agak susah menangkap percakapan yang dimaksud dan terkendala dalam menghafal kosakata.

Cara mengatasi kendala yang pertama, guru biasanya memutar ulang audio sampe 3 kali atau lebih, dan diusahakan setiap pertemuan ada choukainya jadi biar siswa terbiasa. Lalu kendala yang kedua guru biasanya melatih terus pengucapan kosakata yang agak susah sambil siswa mengingat-ngingat. Ini juga sudah cukup efektif tetapi guru masih mencari alternatif pemecahan lainnya. 


\section{Simpulan dan Saran}

Berdasarkan pada hasil penelitian dan pembahasan, maka simpulan dari penelitian ini:

(1) Strategi pembelajaran yang digunakan oleh guru untuk mencapai Sasaran pembelajaran bahasa Jepang pada kelas XI bahasa 1 di SMA Negeri 1 Busungbiu, strategi yang digunakan oleh guru yaitu strategi kontekstual, ceramah, drill, tanya jawab, dan diskusi. Sasaran pembelajaran bahasa Jepang yaitu agar siswa mampu mengembangkan keterampilan dasar berbahasa Jepang yang meliputi aspek mendengarkan, berbicara, membaca, dan menulis.

(2) Kendala yang dihadapi guru dalam mengajar bahasa Jepang yaitu pada saat guru memberikan choukai ke pada siswa, siswa masih agak susah menangkap percakapan yang dimaksud dan terkendala dalam menghafal kosakata.

Berdasarkan temuan selama melaksanakan penelitian ini, maka akan disampaikan beberapa saran, yakni sebagai berikut.

(1) Guru bahasa Jepang di kelas XI bahasa 1 SMA Negeri 1 Busungbiu hendaknya mampu menggunakan strategi pembelajaran yang lebih bervariasi agar minat siswa dalam belajar bahasa Jepang semakin meningkat dan dapat menciptakan suasana kelas yang menyenangkan.

(2) Guru bahasa Jepang di SMA Negeri 1 Busungbiu hendaknya mampu memanfaatkan penggunaan media pembelajaran lainnya, seperti menggunakan kartu bergambar agar siswa merasa tertarik untuk belajar dan tujuan pembelajaran yang diinginkan dapat dicapai.

(3) Perlu diadakannya penelitian sejenis terkait dengan profil strategi pembelajaran bahasa Jepang, khususnya pada tingkat sekolah menengah atas yang dapat dijadikan sebagai acuan dalam pemilihan strategi pembelajaran bahasa Jepang yang digunakan di dalam kelas, khususnya pada siswa sekolah menengah atas.

\section{Daftar Pustaka}

Suandi, I Nengah. 2008. Pengantar Metodologi Penelitian Bahasa. Singaraja: Universitas Pendidikan Ganesha.

Sugiyono. 2010. Metode Penelitian Pendidikan Pendekatan Kuantitatif, Kualitatif, dan R\&D. Badung: Alfabeta

Arikunto, S. 2008. Prosedur Penelitian Suatu Pendekatan Praktik. Jakarta: Rineka Karya.

Sugiyono. 2007. Metode Penelitian Pendidikan (Pendekatan Kuantitatif, Kualitatif dan R\&D). Bandung. Alfabeta.

Arikunto. 2005. Metode Penelitian Kualitatif. Jakarta: Sagung Seto.

Sugiyono. 2007. Metode Penelitian Pendidikan (Pendekatan Kuantitatif, Kualitatif dan R\&D). Bandung. Alfabeta.

Roestiyah. 2008. Strategi Belajar Mengajar. Jakarta: Rineka Cipta.

Nuha, Ulin. 2012. Metodologi Super Efektif Pembelajaran Bahasa Arab. Yogyakarta: Diva Press.

Matakupan, J. 1994. Program Pendidikan Usia Sekolah. Bandung: Tri Pitaka.

Uno, Hamzah B. 2010. Orientasi Baru dalam Psikologi Pembelajaran. Jakarta: Bumi Aksara.

Umbara, Citra. 2006. Pengertian Pembelajaran Kontekstual. Bandung: Citra Umbara. 
JPBJ, Vol. 6 No. 1, Februari, 2020

Djamarah, Syaiful Bahri danAswan Zain. 2013. Strategi Belajar Mengajar. Jakarta: Rineka Cipta.

Dimyati dan Mudjiono. 2006. Belajar dan Pembelajaran. Jakarta: PT. Rineka Cipta.

Aqib,Zainal. 2014. Model-model, Media, dan Strategi Pembelajaran Kontekstual. Bandung: Yrama Widya. 